\title{
Corpus Analysis of English Euphemism in College English (3)
}

\author{
Meihua Wang ${ }^{1}$ \\ ${ }^{1}$ School of Foreign Languages, Inner Mongolia University for the Nationalities, China \\ Correspondence: Meihua Wang, School of Foreign Languages, Inner Mongolia University for the Nationalities, \\ Huolinhe Street, Tongliao City, Inner Mongolia, China. Tel: 86-151-6490-1819. E-mail: \\ meihua_ehome@163.com
}

Received: April 24, 2013 Accepted: May 15, 2013 Online Published: July 4, 2013

doi:10.5539/elt.v6n8p156 URL: http://dx.doi.org/10.5539/elt.v6n8p156

\begin{abstract}
Euphemism, a linguistic and cultural phenomenon, which serves as a lubricant in people's communication, has aroused much interest among scholars worldwide. Many researches on euphemism have already been done in different fields, such as in daily conversations, intercultural communication, advertisements, science, literature, business affairs, etc. For a long time, the researches on English euphemism have been done in terms of semantics, rhetoric and pragmatics, yet few analyzes its usage in textbook. This article attempts to make some analysis of the usage of euphuism in textbook for non-English majors. Then it comes up with some suggestions to teachers concerning how to teach English euphemism in classroom, hoping that this thesis can raise the teachers' and students' awareness of euphemism in English learning and that the suggestions can benefit both teachers and students.
\end{abstract}

Keywords: English euphemism, analysis, College English, suggestion

\section{Introduction}

Euphemism is not only a common strategy in people's language using, but also a kind of cultural phenomenon. Having a great effect on people's daily communication, it can make a harsh topic softer and an embarrassed conversation agreeable while adhering to social communicative conventions. In other words, it saves the faces of both sides and enable people to communicate successfully. From the moment of its emergence, euphemism plays the part of avoiding embarrassment and taboos, showing politeness and concealing feelings. People use euphemism because they fear something and tend to avoid talking about something. With the development of modern society, euphemism has become an indispensable element in people's interactions.

Scholars have an intensive interest in euphemism and have made outstanding contributions to the study of euphemistic expressions. Many researches on euphemism have already been done in different fields, such as daily conversations, intercultural communication, science, literature, business affairs and even media language like newspaper and advertisement. Although many of these studies has referred to the euphemistic strategies in English teaching, but few has been carried out with its using in English textbook. So it is very significant and necessary to conduct a research in this filed.

\section{Literature Review}

\subsection{Major Research in Western Countries}

The word "euphemism" was first used in early 1580s by British writer George Blunt in his Glossographia (1656), where he defined it as "a good or favorable interpretation of a bad word". H. L. Menken carried out a rather detailed analysis of how and why so many euphemisms came into being and became voguish in his book. In 1981, British linguist Hugh Rawson compiled A Dictionary of Euphemisms and Other Double-talk, where he divided euphemisms into positive and negative euphemisms, and conscious and unconscious euphemisms, in addition to a thorough description of the meaning, etymology of each euphemism and its relation to other terms in his dictionary. In 1983, American scholars J. S. Neaman and C. G Silver published another Kind Words: A Thesaurus of Euphemisms that added more detailed description of the history, formation and motives of euphemism.

D. J. Enright (1985)'s Fair of speech, the Use of Euphemism discussed the use of euphemism in one specific domain and put forward that the history of euphemism should be studied within context. Similar focus could also been seen in John Ayto's (1993) Euphemisms in which he pointed out "the euphemistic force of a word is often 
heavily dependent on its context". Similarly, Allan and Burridge (1991) published a book Euphemism and Dysphemism, which offers a functional account of the various expressions of euphemism and dysphemism from a pragmatic perspective. It states that an interesting perspective on the human psyche is to be gained from the study of euphemism used "as a protective shield against the anger or disapproval of natural or supernatural beings" (1991). Euphemism is described as expression that seeks to avoid being offensive, thus defined by reference to face. This book further discusses the correlation between euphemism and context. Furthermore, Enright, Allan \& Burridge and Ayto paid their attention to the correlation between euphemism and context that context could influence the interpretation of euphemism and restrict the application of euphemism.

\subsection{Major Researches in China}

Euphemism has also been a hot topic among Chinese linguists and scholars since 1970s. For a long time, the study mainly focuses on the rhetoric aspect of euphemism as a kind of figure of speech. Chen Wangdao (1976) even provided a definition of euphemism from rhetoric perspective, i.e., one kind of figures of speech, saying something indirectly, but connoting and substituting with roundabout and implicit words or even metaphorical expression. He found euphemism not only in lexical items but also in sentences or even discourse. Chen Yuan (1983) discussed the historical, social and psychological background of euphemism in his book Sociolinguistics and explained the formation of euphemism and its use in different situations.

In 1989, Shu Dingfang enlarged the study scope of euphemism by applying pragmatic theories and proposed three constructing principles (distant principle, relevant principle and sweet-sounding principle) and "self-protective principle", one more principle of the application of euphemism in addition to Politeness Principle and Cooperative Principle.

In 2001, Tian Jiusheng in his article Pragmatic Analysis of Euphemisms argues that when using euphemism people should follow two principles, namely, tact principle and self-protective principle. According to Tian, the tact principle requires the speaker to take the following factors into consideration when using euphemism-when, where, to whom, in what situation, what relation the interlocutors have, and what status the interlocutors have, etc.

In the past twenty years, many books and essays are concerning the topic of euphemism in both English and Chinese. They have studied euphemism from different perspectives of rhetoric (Wu Liquan, 1998), sociolinguistics (Peng Wenzhao, 1999), sociopsychological linguistics (Wang Dechun, 2001), and pragmatics (Tian Jiusheng, 2001; Zhu Yudan, 2009; Li Na, 2010; Gao Yanjun, 2009). All of these pioneers have left their followers a valuable legacy from which they would benefited greatly.

\section{Euphemistic Expressions in College English (Book Three)}

College English (Book Three) is the textbook for Grade 3 non-English majors in Inner Mongolia University for the Nationalities. It has been used for several years. This textbook selects completely original passages of the target language. What's more, it makes efforts to combine the second language acquisition with the cultural input of target language. Because of time limitation, teachers usually only teach five units for a semester. In this part, the author chooses five units from this book, picks out some of the euphemisms and euphemistic expressions in these texts and makes an analysis of them. The following are the examples and the corresponding analysis.

a. I knew also that from January until April my father had gone to eight different doctors. And they all told him not to walk far. (Unit 3)

In this sentence, that the father's seeing eight doctors during four months and the doctors' advice that he had better not walk far imply that his father is seriously ill. The author doesn't want to talk about his father's illness. It's cruel for him to share with others about his father's illness, so he used these two euphemistic expressions instead. Through these two euphemistic expressions, readers can feel the seriousness of the father's situation vividly. At the same time, they protect the author's feelings to a certain degree.

\section{b. But I still don't see why you took all this trouble. And all against your doctor's orders! (Unit 3)}

In these words, the exclamatory mark shows that he is a little unsatisfied with his father's behavior. But as a son, he should respect his father. So he used the euphemistic expression "against the doctor's orders" to show his dissatisfaction with his father's behavior without hurting his feelings. Besides, the author's purpose is to describe his father's strong will in living. To achieve such a purpose, directly mentioning the seriousness of his father's illness will be of no help at all. Leaving some imagination space for the readers to think by themselves will be much better.

\section{c. Twenty times in my life, a doctor has told me to go home and be with my family as long as I could. Told me not}




\section{to work. Not to do anything but to live and enjoy the few days I had left me. (Unit 3)}

The father had faced death many times in his life. Such euphemistic expressions are employed to achieve the father's intention and purpose, that is, to show his pride that he could defeat death and his satisfaction that he could survive until now. In these words, the father emphasizes that his condition is really serious, for it is well known that only when a person is facing death, others, especially doctors, will not persuade their patients to seek doctor's help but to enjoy life as much as possible.

\section{d. Now, I've reached the years the Good Book allows to a man. (Unit 3)}

The father means that he is very old now. "The Good Book" refers to the Bible. This sentence implies that although the father still does not bow before death, he has accepted the fact that he is really old now, consequently, death will come at any time. It is not comfortable for one to mention that he is really old; therefore the father uses this euphemistic expression instead. He also uses euphemistic expression "the Good Book" to refer to the Bible, as we can guess easily. The reason of this is that in western countries, people valve Bible a lot. People have such a respect towards Bible that they don't mention the name directly. So the father uses the Good Book instead to show his respect.

e. After these years, your time is borrowed, and then, you go back to the place you knew and loved. (Unit 3)

In this sentence, the father uses "to go back to the place one know and love" to mean "to die". From this euphemism, the father's strong love for earth and the ground could be clearly felt. So he hopes that when he dies, he could return the place where he spends his whole life. As in all cultures, it is cruel to talk about death. People tend to avoid this word in their lives, so they use many euphemistic expressions instead. This euphemistic expression "go back to the place you knew and loved" not only avoids mentioning the word death, but also has the function of showing the father's love for the place where he was born and grew up.

\section{f. Many months ago he told me I had outlived my usefulness, and he wished me well. (Unit 4)}

When consulting an euphemism dictionary, readers could find out that euphemistic expressions concerning occupation take a large part. Here the author uses "I had outlived my usefulness" to mean "I am no longer useful now", and "he wished me well" to mean that "I am dismissed or fired". "Outlived one's usefulness" is used when someone is no longer needed for a position. As is well known, people can only make their living with the money they earn from their work, therefore, being fired from one's job will really endanger their lives and undoubtedly cause uncomfortable feelings or even feeling of despair. Therefore, when it is time to tell others that they are fired, people will choose their words very deliberately. Using these euphemistic expressions not only achieves the purpose of notifying the author that he is fired, but also avoids hurting the author's feelings too much.

g. In the sentence "Barring a gin-induced stupor, how can anyone be relaxed during an interview”. (Unit 4)

The author uses "a gin-induced stupor" to mean "drunkenness". The author always thinks himself higher than others because he has received high education and has unusual ability. Therefore, when he wants to express he has been drinking all day, he also wants to distinguish himself from those common people that he believes to be. "A gin-induced stupor" means drinking too much gin and becoming drunk. In fact, he is not any better than those common people he always despises. When he could not find a satisfactory job, he drinks all day long to make himself drunken, so as to forget his pain and suffering. The author uses the euphemistic expression "a gin-induced stupor" just to show his superiority, yet without showing it too openly.

\section{h. Would they be better off without me. (Unit 4)}

Here the author uses "be better off" to mean "rich". In western countries, people don't talk about their wealth directly, because it seems impolite to show off one's wealth in front of others, otherwise, they will be considered as arrogant people. So there are many euphemistic expressions to stand for rich.

\section{i. We have to go out tonight, and I was just wondering if... (Unit 4)}

In the expression "I was just wondering if..." the speaker's purpose and intention of being polite influences his choice of words. Generally speaking, when people want others to help them, especially for those they are not familiar with, they must pay attention to their manner of speech, that is, being very polite. Here, the speaker wants to ask one of the author's daughters to babysit their children. They are unfamiliar with each other, so he is very polite in asking whether they are available to help them. The author just uses this euphemistic expression "I was just wondering if..." to show his politeness, which is very commonly used in our daily life.

j. The kitchen smelled dank and unused, and the opening of the door dislodged a flake of green-painted plaster. A black dress someone had given her mother lay over the chair...She hung her coat on a hook in the room she shared with her mother. A crash of the kitchen door caused a reverberation in the window sill. (Unit 5) 
The author's purpose to describe the girl's home is to make the readers feel the poor condition of the girl's family clearly. However, what's unique about this essay is that he never mentions the word "poverty" or "poor" throughout the story. However, he makes his readers feel the extremely bad economic state of the family clearly by using these euphemistic expressions

\section{k. She heard her mother's voice, hard and sounding more Southern than usual. (Unit 4)}

In this sentence, "sounding more Southern than usual" is used to imply her social status - she is very likely an Afro-American. In this expression, the author's strong sympathy for the little girl and her family makes him choose to express in an euphemistic way. Therefore, he avoids mentioning the color of their skin directly, and avoids describing them to be inferior. Even when mentioning her mother's accent, he uses "Southern" instead. This is because in southern America, there are a lot of large plantations where great number of black slaves spend their whole life. Therefore, the author uses this euphemistic expression to suggest the social status of the family.

\section{It made a mist come before her eyes. (Unit 4)}

This sentence implies that she cried. After the teacher and the little girl's classmates showed their great appreciation to her composition without any despise and prejudice, of which she was afraid at first. The little girl was in fact deeply moved and excited. In that situation, if the author only used the expression "she cried", there would not be any beauty in it at all. This euphemistic expression "A mist before her eyes" instead becomes much more beautiful and vivid. The readers can even picture a lovely picture of the little girl in their minds and feel the little girl's excitement clearly by the beauty of euphemistic expressions.

$\mathrm{m}$. And if we vote the accused guilty, we've got to send him to the chair. (Unit 7)

The author uses euphemistic expression "send someone to the chair" to mean "death penalty". In western countries, the direct mentioning of death penalty will cause uncomfortable feelings to the hearer, then the use of these euphemistic expressions will be easy to understand. The chair originally refers to the tool that people seat themselves on. But euphemistically speaking, the chair here refers to a kind of electric chair which is used to execute death penalty by using electricity. "The chair" is a commonly used euphemism when people talk about death penalty using electricity because it always sounds a bit cruel no matter the listener knows the criminal or not. Consequently, expressions concerning the chair also appear. When people want to express killing someone by using electricity, they can say "send someone to the chair" or "put someone in the chair".

n. Now perhaps the gentleman down there who's disagreeing with us could let us know what you're thinking, and we might be able to show where you mixed up. (Unit 7)

The author uses "mixed up" to mean "puzzled" or "confused", and the expression "we might be able to show..." in fact belongs to indirect speech expressions. His double purposes of being polite and reminding the eighth juror decide his adoption of these euphemistic expressions. The foreman of course could not blame the Eighth juror's mistake directly even though he thinks so and agrees with all the other eleven jurors. However, he thinks he had better let others to point out the boy's mistake and let the boy realize his own mistakes, so he uses "we might be able to show where you mixed up", which in fact means that "we could make you understand where you are wrong". By using these euphemistic expressions, the author conveyed his meanings clearly to the boy, and at the same time, he protected the boy's face and feelings.

Through the above analysis, we may infer that due to the significant contributions brought by former studies to English euphemism teaching, the education circle has already been aware of the significance of euphemism in language teaching and also made some efforts, such as paying attention to euphemism usage when choosing articles for English learners.

\section{Suggestions for Teaching English Euphemism}

\subsection{Teaching Formation of Euphemism}

We have learned that from a linguistic point of view, there are various ways of forming English euphemism. Generally speaking, these means can be divided into four kinds: lexical technique, grammatical technique, rhetorical technique and pragmatic technique. So teachers should at first teach the students the formation of euphemism to let them have a general idea, which is the foundation for students to use euphemism successfully.

\subsection{Teaching Euphemism with Reference to Chinese}

Speakers can understand the pragmatic rules of their own language and knows what is proper and what is improper in communication. This can be applied to both Chinese and a foreign language. The same phenomenon exists in the two languages. On the one hand, learning euphemism is a part of pragmatic competence. Most 
languages have this kind of phenomenon. In Chinese, euphemisms, like “大概”, “有点”, “稍微”, “很”, “我认为”, “可能”, “据说”, are used frequently. However, Chinese is much different from English. Sometimes a speech is considered to be polite and proper in Chinese may not so in English. Therefore, when teaching students, the teacher should make a comparison of the use of euphemism between English and Chinese. In this way, the students can have a more clear understanding of these expressions and make full use of the same points between English and Chinese.

\subsection{Teaching Euphemism by Explaining Cultural Differences}

Language and culture are closely related to each other. Sometimes, what is appropriate in one culture may not appropriate in another culture. Therefore, when we study a language, we should take the culture into consideration. In the study of euphemism, we should pay attention to the culture aspect. Likewise, in language teaching, teachers should think much of culture when teaching the proper use of euphemism.

There are a lot of differences between English and Chinese culture. In China, it's very common for people to talk about income, marriage, and family life, even in public places. Chinese people regard this as a kind of care and concern. However, in English culture, these topics are considered to be taboos and people usually avoid mentioning them so as not to invade other people's privacy. Here is one example, The Chinese and the English also have different feelings about "old age". A Chinese is proud of being old, because the Chinese culture places a high value on eldership. To be old means to be more experienced and knowledgeable. Yet westerners have negative feelings about age. Elder people in English culture will feel embarrassed if others call them "old" and treat them like this, because being old is considered to be a miserable thing. Bearing the cultural differences in mind, it is possible for language learners to acquire the ability to speak properly and euphemistically in different situations.

\section{Conclusion}

As we all know, euphemisms are rich in people's daily communication. It can help people form a positive communicative atmosphere to establish harmonious social relationships and eventually to achieve communicative goals. With the development of modern society, it has become an indispensable element in people's interaction. In foreign language learning process, euphemistic expressions are also capable of promoting successful communication. Therefore, euphemism is of great significance in English learning and teaching.

According to the above analysis, we find that the textbook has already paid attention to the usage of euphemism. Studying related euphemisms in articles for college learners, this paper come up with some suggestions to teachers concerning when to use English euphemism in classroom and how to teach English euphemism, hoping that this thesis can arouse the teachers' and students' awareness of euphemism in English learning and that the suggestions can benefit both teachers and students.

\section{References}

Allan, K., \& Burridge, K. (1991). Euphemism and Dysphemism: Language Used as Shield and Weapon. London: Oxford University Press.

Chen, W. D. (1976). The Origin of Rhetoric. Shanghai: Shanghai Education Press.

Chen, Y. (1983). Sociolinguistics. Beijing: The Commercial Press.

Enright, D. J. (1985). Fair of Speech: the Uses of Euphemism. London: Oxford University Press.

Hugh Rawson. (1981). Rawson's Dictionary of Euphemisms and Other Double Talk. Revised Edition. New York: Crown Publishers, Inc.

John Ayto. (1993). Dictionary of Euphemisms. London: Bloomsbury Publish Limited.

Li, N. (2011). A Brief Analysis on the Pragmatic Function of Euphemism in Cross-Cultural Communication. Science and Technology Information, 1. Retrieved from http://www.cnki.com.cn/Article/CJFDTotal-KJXX201001141.htm

Neaman, J. S., \& Silver, C. G. (1983). Kind Words: A Thesaurus of Euphemisms (Expanded and Revised Edition). New York: Facts on file, World Publishing Corp.

Peng, W. Z. (1999). Euphemism: the Mapping of Culture onto Language. Foreign Languages, 119. Retrieved from http://www.cnki.com.cn/Article/CJFDTotal-WYXY901.008.htm

Shu, D. F. (1989). On English Euphemism. Foreign Language, 3. Retrieved from 
Tian, J. S. (2001). Pragmatic Analysis of Euphemisms. Foreign Languages in Fujian, 2. Retrieved from http://202.207.22.5/D/Periodical_wgyywx200102004.aspx

Wang, D. C. (2001). Social Psycholinguistics. Shanghai: Shanghai Foreign Language Education Press.

Wu, L. Q. (1998). On the Mental Mechanism of Euphemism. Rhetorical Studies, 86. Retrieved from http://www.cnki.com.cn/Article/CJFDTotal-XCXX199802004.htm

Zhu, D. Y. (2009). On Pragmatic Function of English Euphemism. Education for Chinese After-school, 16. Retrieved from http://www.cnki.com.cn/Article/CJFDTotal-XWLL2009S4258.htm

\section{Copyrights}

Copyright for this article is retained by the author(s), with first publication rights granted to the journal.

This is an open-access article distributed under the terms and conditions of the Creative Commons Attribution license (http://creativecommons.org/licenses/by/3.0/). 